\title{
A Socratic Teaching Method to Foster Critical Thinking Skills among Nursing Students in Our Clinical Classroom Settings
}

\author{
Asso Prof (UB)

\section{*Corresponding Author} \\ Dr. Selvia AMA MSN, CRM, MD (AM)
}

Dr. Selvia AMA MSN, CRM, MD (AM)*

\section{Article History}

Received: 01.07.2020

Accepted: 09.07.2020

Published: 12.07.2020

\begin{abstract}
The purpose of a Socratic way is to stimulate critical thinking. Students are provided with unpredictable patient scenarios that change constantly during play. The instructor helps facilitate play by encouraging questions throughout the game. Discussion after answering the questions and even adding questions by the instructor and/or students is encouraged for a richer experience when valuable "teaching moments" present themselves. Students will participate by answering questions and thinking through situations. The instructor may wish to allow students the option of using books, smart phones, or other resources to help answer the questions. This game implements all facets of the nursing process: assessment, diagnoses, planning, implementation, and evaluation. There are heart and lung sounds for audio learners, role playing for hands on learners, and photographs for visual learners.
\end{abstract}

Keywords: Socratic Foster Skills Nursing.

\section{INTRODUCTION}

Critical thinking is a skill required by nurses in order for sound clinical decisions to be made with optimal patient outcomes. Previous nursing education specific strategies, aimed at developing critical thinking, include highfidelity simulation, case study discussions, concept-mapping, and reflective writing. Post-graduation nurse residency programs have had some success in preparing the new graduate nurse to take on the challenges and demands of the profession.

Education is a light which shows the right direction to mankind to surge. The purpose of education is not just making a student literate but also adds critical thinking [1, 2]. Nursing graduates must be prepared to practice as competent healthcare professionals in a highly complex, diverse, and ever-changing environment. The learning process in nursing is very unique because nursing student should be able to perform the activities of the profession in live situations. Critical thinking is crucial to providing safe, competent, and skillful nursing practice [3].

Nurse educators are obligated to create learning environments that support critical thinking. Not only it is important what students learn, but also equally important that how they learn [4]. Teaching strategies that involve experience by "doing" and dialogue with "others" will promote more significant learning. Creativity can be developed and innovation benefits both students and teachers.

A teacher tries there level best to impart knowledge as the way student understood it. So, any communication methods that serve this purpose without destroying the objective could be considered as innovative methods of teaching.

The use of innovative methods in health care institutions has the potential not only to improve education, use of more creative methodologies like utilizing. Socratic teaching method and a range of other creative teaching strategies in teaching enhance the competencies rather than lecture method and demonstration to teach across all specialized sectors.

Copyright @ 2020: This is an open-access article distributed under the terms of the Creative Commons Attribution license which permits unrestricted use, distribution, and reproduction in any medium for non commercial use (NonCommercial, or CC-BY-NC) provided the original author and source are credited. 


\section{Innovative in Teaching Methodology}

There are various Instruction strategies for classroom \& clinical are Lecture, discussion, demonstration, simulation, laboratory, seminar, panel, symposium, problem solving, problem based learning (PBL), workshop, project, role- play (socio drama), clinical teaching methods, case based learning, clinical simulation, programmed instruction, self-directed learning(SDL), micro teaching, computer assisted instruction (CAI), computer assisted learning (CAL), blackboard learning (Web based learning), Mind mapping/Concept mapping, Storytelling, Field trips, Games, Use of good Sense of humour etc. But all methods are not emerging \& innovative teaching methods.

Innovations depends on the teacher that how they utilizes the instructional strategies while delivering lectures or teaching in clinical. Innovative applications should be evidence based.

\section{A teacher must see before class that}

A. Relevancy of selection of new approaches for using technology as a teaching tool.

B. New insights for using positive behavior supports.

C. Strategies for reaching students who are negative toward college.

D. Techniques for teaching unmotivated learners.

E. Special considerations for reaching economically disadvantaged students.

F. Project-Based Learning Strategies.

Our Goal is to create interactive ways to engage students in active learning while stimulating critical thinking; to serve students and seasoned professionals alike; and to give educators innovative ways to bridge the gap between knowledge of content and the ability to apply that knowledge. We provide games that engage students in learning while having fun doing it. Our games create unpredictable, constantly changing patient case scenarios[5]. Problems arise that students solve as teams. As students say, "It's almost just like being on a real oor!" Instructors lead the play and have opportunities to grab those precious "teaching moments" that only occur irregularly in real clinical settings. Take your classroom and clinical to the next level.

Ponder: The Socratic Way Geared towards students and nurses in medical-surgical specialty. Level is for students who have completed at least half of an adult health or medical surgical course or registered nurses. Engage students in class and clinical by playing an entire activity or creating unfolding case studies for class-the writes case studies for you!

Ponder Pack Cards- set of Booster Cards that have a concentrated focus on pharmacology, nutrition and oxygenation will add an additional level of challenge to the original Ponder game.

The Call Light activity Combined with low fidelity mannequins in a nursing lab, this game supports Ponder: The Socratic Way to simulate a real nursing thinking.

This activity produces unpredictable, constantly evolving patient case scenarios with problems that must be solved throughout play. Socratic way weaves the entire nursing process throughout the activity, and students must pull together principles of pathophysiology, pharmacology, health assessment, psychology, and sociology in the holistic approach to nursing in order to solve problems. This teaching methodology is played in a fun and non-threatening environment. Students LOVE being able to bounce ideas o of each other and competing in this manner. Our patients are a roll of the dice. Patients and scenarios are created by rolling the dice and drawing cards throughout the activity. Students vie for the highest number of "Status Improved" cards awarded when they answer questions correctly and the fewest number of "Suered Setback" cards when they answer incorrectly in order to win the task[6,7].

The games implement all facets of the nursing process: assessment, diagnoses, planning, implementation, and evaluation; and also incorporate things that appeal to all types of learners. There are heart and lung sounds for audio learners, role playing for hands on learners, and photographs for visual learners.

The potential to utilize the games for interdisciplinary play are immense; and some can be combined with high fidelity simulation for added challenges.

\section{CONCLUSION}

Strategies that stimulate the development of critical thinking skills are problem based in nature, and require active involvement in the learning experience, as well as an inquiring mind and active participation of students in the task. 
The Socratic Way is a much needed activity in nursing education, bridging the gap between theory and the real world by simulating the type of critical thinking skills nurses must use every day such as assessment, diagnoses, planning, implementation, and evaluation, and allowing students to practice and apply those skills in a non-threatening environment.

\section{REFERENCES}

1. American Association of Colleges of Nursing. The essentials of baccalaureate education for professional nursing practice. Available from: http://www.aacn.nche.edu/education-resources/baccessentials08.pdf . Washington, DC: AACN

2. Mann, J. (2012). Critical thinking and clinical judgment skill development in baccalaureate nursing students. Kans Nurse, 87: 26-30.

3. Tesoro, M. (2012). Effects of using the developing nurses' thinking model on nursing students' diagnostic accuracy. J Nurs Educ, 51: 436-443. PMid:22694666 http://dx.doi.org/10.3928/01484834-20120615-01

4. Popil, I. (2011). Promotion of critical thinking by using case studies as teaching method. Nurs Educ Today. $31: 204-$ 207. PMid:20655632 http://dx.doi.org/10.1016/j.nedt.2010.06.002

5. Billings, D.M., Halstead, J.A. (2009). Teaching in Nursing: a guide for faculty. St Louis: Saunders Elsevier.

6. Hovancsek, M. T. (2007). Using simulations in nursing education. In P. R. Jeffries (Ed.), Simulation in nursing education: From conceptualization to evaluation. New York: National League for Nursing, 73-85

7. http://kerrimahoney.com 